\title{
Opinions of Graduate Students of Social Studies Education About Qualitative Research Method
}

\author{
Feyzullah Ezer ${ }^{1} \&$ Selda Aksüt ${ }^{2}$ \\ ${ }^{1}$ Faculty of Education, Firat University, Elazıg, Turkey \\ ${ }^{2}$ Institute of Educational Sciences, Firat University, Elazıg, Turkey \\ Correspondence: Selda Aksüt, Institute of Educational Sciences, Firat University, Elazıg, Turkey. E-mail: \\ selda.aksut@hotmail.com
}

Received: July 28, 2020

Accepted: November 6, 2020

Online Published: February 20, 2021

doi:10.5539/ies.v14n3p15

URL: https://doi.org/10.5539/ies.v14n3p15

\begin{abstract}
The purpose of the study is to determine the opinions of graduate students from social studies education regarding the qualitative research method. The study was conducted in accordance with the phenomenological design, one of the qualitative research designs. The sample group of the study was composed of 25 postgraduate students including 11 females and 14 males studying in the Department of Social Studies Education in Division of Turkish Language and Social Sciences Education of Educational Sciences Institute, in Firat University in the spring semester of the 2019-2020 academic year. The sample group was determined with criterion sampling, one of the purposeful sampling methods. The data of the study were obtained through interview method by using semi-structured interview form. Content analysis method was used in the analysis of the data obtained in the study and the qualitative data analysis program was employed to assess the data. It was determined as a result of the study that the graduate students expressed the qualitative research method as sensitivity to the natural environment, in-depth examination of a social phenomenon, and revealing perception and experiences. Since the qualitative research experience positively affect the knowledge and skills of the graduate students towards the study, they should be included more in the research environment and process. In addition, during the qualitative research process, graduate students should be encouraged and directed to academic activities.
\end{abstract}

Keywords: qualitative research method, social studies education graduate students, social studies education, teaching of qualitative research method

\section{Introduction}

Human beings have been trying to understand themselves, what is happening around them, the world and the universe since their existence. For this purpose, they have conducted researches in many fields and these researches have become more systematic over time. Sense of curiosity has become effective in conducting researches and people have approached science and systematic control of scientific processes with each passing day (Şahin, Uysal, Saraç, \& Gündoğdu, 2019). Science actually stems from the desire of people to know themselves and their circle and dominate and control them whenever they want (Karasar, 2004). In short, science is a collection of information that arises from the desire of man to understand and make sense of the environment and nature.

The basis way that individuals and societies use to obtain information and solve their problems is science or research. Science is information about facts, obtained by scientific methods (Büyüköztürk, K1lıç Çakmak, Akgün, Karadeniz, \& Demirel, 2013). Research is the attempt to solve a particular problem or questions in a systematic and logical way (Yıldırım, 1999). Scientifically valuable information is obtained through scientific ways. This scientific way includes doing scientific research involving many stages (Harman \& Şeker, 2019). Scientific researches including many stages in a scientific process is generally conducted in two main areas including quantitative and qualitative researches.

The positivist paradigm, which prevailed until the beginning of the $20^{\text {th }}$ century, has become more controversial as a result of the developments in social sciences and the production of new concepts and approaches that are more appropriate to the nature of social sciences (Spooner, 2002, cited by Balc1, 2011). In this context, the positivist thinking approach and quantitative research methods, which have existed as the only dominant series of values for 
many years, have started to be replaced with qualitative research methods in social sciences with the increasing criticism on this series of values (Aydın, 2018). It was seen that quantitative research methods were replaced with qualitative research methods in the $20^{\text {th }}$ century (Kartar1, 2017). It is seen that qualitative research methods have increased rapidly in recent years and researchers from different disciplines such as educational sciences, program evaluation, public administration, organization science, family researches, linguistics, psychology and sociology conducted their research in accordance with qualitative research (Miles \& Huberman, 2016).

Qualitative research means long-term and versatile in-depth examination of certain facts and events within their natural environment (Saban, Koçbeker Eid, Saban, Alan, Doğru, Ege, Arslantaş, Çınar \& Tunç, 2010). In other words, qualitative research is an approach emphasizing the holistic and realistic manifestation of the events in the natural environment they are attached to and using different qualitative data collection tools such as observation, interview and document analysis (Yıldırım, 1999). In short, qualitative research is the researches where certain cases and event are examined in depth in their natural environments by using qualitative data collection tools and also a qualitative process is followed to understand the perceptions and experiences of individuals.

The purpose of the qualitative researches is to study and investigate a certain part of social life. In fact, qualitative researches are the studies in which a qualitative process is followed to understand the perception and experiences of individuals or societies about a particular subject (McKusker \& Gunaydin, 2015). In order to conduct qualitative research, it is necessary to be determined in the qualitative research process by considering a problem and the time and resource demands of this problem. Qualitative researches may act together with quantitative researches but they should not be seen as an alternative research for quantitative researches (Creswell, 2016). In other words, qualitative research methods cannot replace quantitative research methods, that is, these methods cannot be used interchangeably. These two research methods have important advantages for the education field (Yildirım, 1999).

Qualitative research, that makes the world visible, is composed of a series of interpretative material applications such as field notes, interviews, photographs and researcher diaries. Qualitative research has an interpretive and natural approach to the world (Denzin \& Lincoln, 2011). The fact that qualitative researches present a picture of real life since they focus on naturally occurring daily events constitutes one of their strengths (Miles \& Huberman, 2016). Therefore, qualitative researches are the studies that try to investigate, understand, and make sense of a situation, event, and phenomenon in their natural environment.

Qualitative research methods generally allow to get deep and detailed information about the subjects (Patton, 2014). In this respect, the researcher acts like an explorer, traces the truth by asking additional questions, and gives importance to the subjective perspective of addressee (Karataş, 2015). Qualitative researches offer a rich and holistic content along with a strong potential to uncover complex situations (Miles \& Huberman, 2016).

The quality of qualitative researches is heavily based on the methodological skill, sensitivity, and honesty of researcher. Because the researcher is a tool themselves in qualitative research. Obtaining useful and reliable qualitative findings depends not only on observation, interview, and content analysis, but also education, information, practice, creativity, discipline, and hard work (Patton, 2014).

The rapid development in information technologies today has led to the formation of information societies. Therefore, this development that has taken place in information technologies has directly affected the education systems and made it necessary to train qualified individuals who can adapt to the $21^{\text {st }}$ century. In this case, education systems must train the specified manpower (Saracaloğlu \& Kaşl1, 2001). Universities have important roles and responsibilities in developing and modernizing the society in all aspects and raising this manpower (Işıksoluğu, 1993). In Turkey, universities are the leading source in training scientist, researcher, and expert (Çıkrıkçı Demirtaşl1, 2002). It is very important to improve research skills of graduate students by increasing their professional responsibilities throughout the education process (Som, 2017). The reason is that the research skills and habits these students have developed affect all the researches they will do for the rest of their lives (Barrett, 2005).

Although the relevant laws and regulations of the Turkish Education System emphasize the researcher characteristics of the schools and individuals in the curriculum and aim the training of researcher individuals, research training is not seen to be sufficient in terms of content, method and level (Saracaloğlu, 2008). In this context, one of the most important problems of today's universities is that the line and relationship between education and training and research-development are not clarified. One of the main problems of the universities in Turkey is the insufficient research-development budget and insufficient "research culture" that will use this budget (Öztemel, 2013).

When the related literature is examined, there are many international studies on the qualitative research method and teaching the method (for example, Cobb \& Hoffart, 1999; Breidenstein, Liberatore, Lioi, Miro, Weber, \& 
Stoeck, 2001; Rifkin \& Hartley, 2001; Blank, 2004; Efinger, Maldonado, \& McArdle, 2004; Breuer \& Schrezer, 2007; Li \& Seale, 2007; Booker, 2009; Turner \& Crane, 2016). It is seen that the studies on this subject is limited in Turkey (for example, Saban, 2007; Ersoy, 2015; Som, 2017; Sahin et al., 2019). Qualitative research method is among the important subjects that the students are required to acquire throughout their graduate education process. The aim of this study is to determine the opinions of the graduate students of social studies education about qualitative research method, teaching this method and their research experiences. In this sense, it is predicted to be beneficial in terms of qualitative research method and teaching this method to the researchers who have interest in qualitative research method and contribute to the literature.

The main purpose of the study is to determine the opinions of graduate students of social studies education about qualitative research method. For this purpose, answers to the following questions were sought:

1) How do graduate students define the qualitative research method?

2) What are the strengths and limited aspects of the qualitative research method?

3) What are the opinions of graduate students about the place and importance of qualitative research method in educational studies?

4) What are the criteria to be considered when conducting qualitative research?

5) What are the stages that graduate students have difficulty while conducting qualitative research?

6) What are the suggestions of graduate students for the solution of the problems they face while conducting qualitative research?

7) What are the evaluations of graduate students regarding competence of their knowledge and skills in continuing qualitative research?

8) What are the thoughts of graduate students about what they gain as a result of their qualitative research experience?

9) What are the evaluations of graduate students regarding the graduate education given in the teaching of the qualitative research method?

\section{Method}

\subsection{Design of the Study}

The study was conducted in accordance with the phenomenological design, which is one of the qualitative research designs. Phenomenological studies aim to reveal how an individual experience and perceive the world about a phenomenon as a result of his/her interaction with the world as well as to describe, understand, and interpret the structure of the phenomena (Çilesiz, 2011).

\subsection{Study Group}

The sample group of the study was composed of 25 graduate students studying in the Department of Social Studies Education in Division of Turkish Language and Social Sciences Education in Educational Sciences Institute in Firat University during the spring semester of 2019-2020 academic year. The sample group was determined with criterion sampling that is one of the purposeful sampling methods in terms of conducting in-depth research depending on the purpose of the study and being suitable for the subject of the study. In criterion sampling, observation units meeting the criteria set for the sample in the study can be composed of individuals, events, objects or situations having certain qualities and these formed units are taken into the sample (Büyüköztürk et al., 2013). In this study, the criterion was that the graduate students took the qualitative research methods course or one of the courses in which qualitative research methods are taught (scientific research methods, research methods, etc.) and the students conducted a qualitative research or carried out a study by using qualitative research method in the course. In this context, students continuing graduate education in the department of social studies education were reached and the study was conducted with 25 students.

Volunteering principle was taken into account in including the graduate students in the study. Table 1 shows distribution of graduate students participating in the study according to their gender. 
Table 1. Distribution of the sample group according to their gender

\begin{tabular}{ccc}
\hline Graduate education & Gender & Graduate student \\
\hline \multirow{2}{*}{ Graduate } & Female & 10 \\
& Male & 10 \\
\hline \multirow{2}{*}{ PhD } & Female & 1 \\
& Male & 4 \\
\hline \multirow{2}{*}{ Total } & Female & 11 \\
& Male & 14 \\
\hline
\end{tabular}

A total of 25 postgraduate students including 11 females and 14 males participated in the study. These students consisted of a total of 20 graduate students including 10 females and 10 males and a total of $5 \mathrm{PhD}$ students including 4 males and 1 female.

\subsection{Data Collection Tool and Data Collection}

The data of the study were obtained by using interview technique. The purpose of the interview method is both to learn the answers to the questions asked and to try to understand the experiences of the participants on the subject, how they perceive and express the subject (Seidman, 2006). In accordance with the purpose of the study, the data of the study were obtained with semi-structured interview technique. The semi-structured interview is important in terms of giving the opportunity to the interviewee to express him/herself and to get in-depth information on the subject investigated (Büyüköztürk et al., 2013). Therefore, the semi-structured interview form developed by the researchers was used in the study. This form was prepared with the aim of getting the same kind of information from different people by focusing on similar topics. It provided the interviewer with a list of questions and topics to be discovered during the interview (Avc1, 2008).

While preparing the interview form, firstly, the literature was reviewed and the studies on the subject were examined in detail. The prepared draft was then submitted to the opinions of three faculty members of the Department of Social Studies Education in Division of Turkish Language and Social Sciences Education in the Faculty of Education, Firat University. It was regulated in accordance with the feedback and the interview form was made ready for the application. In the study, the interview form consisting of 9 questions developed by the researchers was used as the data collection tool. Ethical permission was obtained from Social Sciences and Humanities Researches Ethics Committee of Firat University (03/03/2020-382205) for this research. Before starting the interviews, the sample group was informed about the research subject and the questions included in the interview form by providing brief information and then the interviews were conducted.

\subsection{Data Analysis}

In the analysis of the data obtained in the study, content analysis method was used. "Content analysis is a scientific approach that investigates the social reality through classifying objectively and systematically the message contained in verbal, written and other materials in terms of meaning and/or grammar as well as converting them into numbers and making inferences" (Tavşancıl \& Aslan, 2001). According to Bilgin (2014), this analysis aims to comment from the items observed and described in messages but to get rid of subjective factors in interpretation.

Qualitative data analysis program was used to assess the data. This analysis program was used in the study since it eases data storage and coding and helps to analyze. The data obtained from the interviews were transferred into the computer environment as they were and they were made suitable for analysis. In order to facilitate the analysis of the expressions in the interview, these expressions were coded into short and meaningful symbols in accordance with the purpose and questions of the study. Draft themes were determined by establishing correlation with the related literature and the codes were arranged according to these draft themes. Later, these draft themes were checked and put into final form. The relationship between the themes was determined and the main and sub-themes were gathered under the study questions. By preparing a code and theme list, the data were organized so that this list is consistent within itself. Thus, how many participants emphasized the same theme was revealed and areas where themes were concentrated more were determined. The obtained themes were then visualized and presented in models in order to provide a clearer and more comprehensive view. These models were interpreted by including direct citations from the participants' opinions. The participants' opinions about themes are given in italics in inverted commas. Besides, personal information of the participants was given by the codes directly found at the beginning of the citations. In these codes: "S" abbreviation refers to students, numbers " 1 " and "2" refer to the order of the students, "M" abbreviation refers to graduate students and "PhD" abbreviation indicate $\mathrm{PhD}$ students, the letters " $\mathrm{M}$ " and " $\mathrm{F}$ " indicate the gender of students. 
It is important to ensure the validity as a result of the study in qualitative researches. Reporting comprehensively the data collected as a result of the study and explaining how the researchers found the results in detail are among the criteria that are considered important for ensuring validity in a qualitative research (Yıldırım \& Şimşek, 2016). Ensuring validity is based on the evaluation of the accuracy of the research results in terms of perspective of the reader, participant, and researcher (Creswell \& Miller, 2000). In the study, how the research results were obtained to ensure validity was explained in detail and they were reported in detail in the results section. Thus, the reader, participant and researcher were ensured to evaluate the accuracy of the study results.

In order to ensure the reliability of the research and eliminate the individual effects that may be encountered during the data coding process, the coding was made upon evaluation of the interview data independently by different researchers (coders) conducting the study and these coding were then compared and numbers of agreement and disagreement were determined in order to find out whether there was compatibility between different coders so that the reliability of the study was calculated. Reliability was calculated using the following reliability formula of Miles and Huberman (1994/2016); "reliability=number of agreement/total agreement + number of disagreement". The reliability value calculated according to the reliability formula was determined as $91 \%$. In the study, it was determined that the desired level of reliability was obtained since the agreement was $91 \%$ as a result of the expert and researcher evaluations. According to Saban (2009), the desired level of reliability is provided when the agreement is $90 \%$ and above as a result of the expert and researcher evaluations in qualitative researches.

In order to ensure the reliability and validity of the study, the credibility, transferability, consistency and confirmability strategies stated by Erlandson, Harris, Skipper and Allen (1993) were used. Expert review and participant confirmation for evaluating the credibility, detailed description and purposeful sampling to increase transferability, consistency review for ensuring consistency and confirmation review to ensure confirmability were carried out to ensure validity and reliability. In the study, expert review was performed by having a person, who is specialized in research and qualitative research methods, review the study in order to evaluate credibility. The obtained data and the results related to these data were confirmed to the participants and the participant confirmation was made. In order to increase transferability, the raw data were rearranged according to the concepts and themes emerging as a result of the analysis and detailed descriptions were made by sticking to the nature of data and without adding any comments. Then, purposeful sampling method, which has tendency to reveal general and specific information, was used in qualitative research. In order to ensure consistency, a consistency review was conducted which reveals whether or not the researchers are consistent in the research process by looking from the outside. In order to ensure confirmability, an expert was asked to compare the raw data with the results obtained by the researchers in the study and to evaluate if or not the researchers employ the confirmation mechanism and the confirmation examination was made.

\section{Findings}

Nine main themes were determined about the opinions of graduate students in social studies education regarding the qualitative research method.

\subsection{Results Related to Qualitative Research Method}

Opinions of social studies education graduate students about the qualitative research method were obtained and this theme was found to have seven sub-themes according to these opinions. Figure 1 shows the model and number of loading for this theme. 


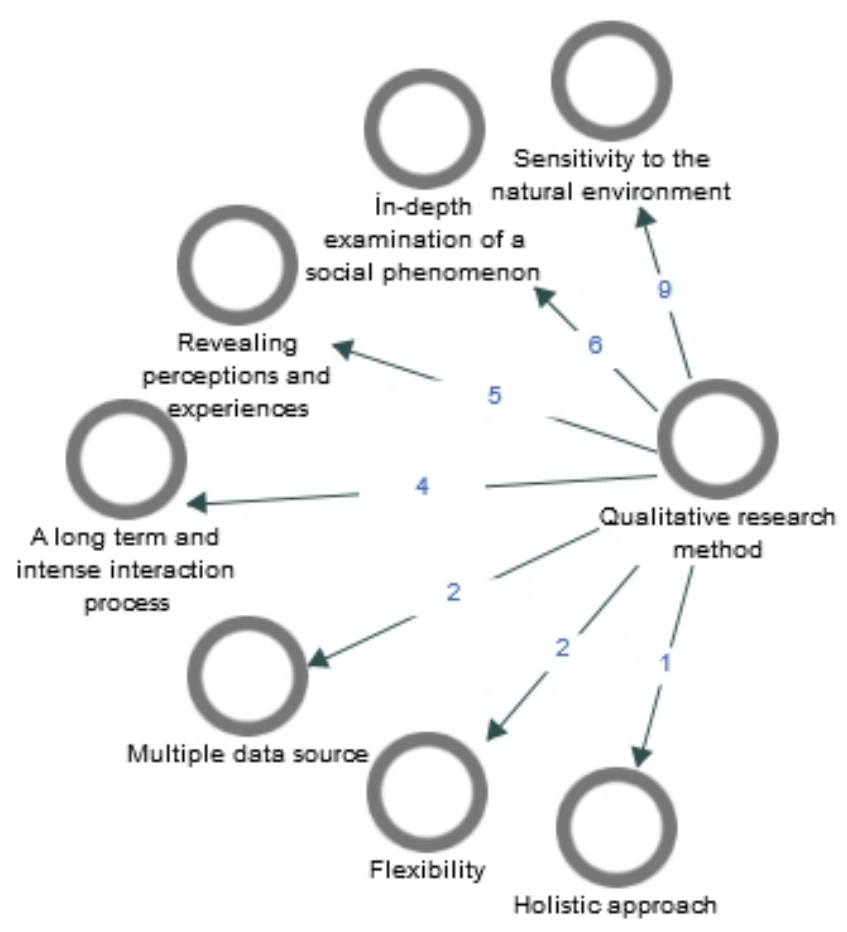

Figure 1. Model for qualitative research method

When the opinions of the graduate students about qualitative research method were evaluated; the highest number of loadings was seen to be in "sensitivity to the natural environment" sub-theme. The other sub-themes determined for the qualitative research method were determined as "in-depth examination of a social phenomenon", "revealing perceptions and experiences", "a long term and intense interaction process", "multiple data source", "flexibility" and "holistic approach" with minimum number of loading. Some sub-themes and participant views are given below.

While the participant (S.4.M.F.) who associated qualitative research method theme with "sensitivity to the natural environment" sub-theme expressed her opinion as "Qualitative research expresses the process in which certain events are examined for a long time and very intensely in their own natural environment.", another participant (S.6.M.F.) is seen to express qualitative research method as examining certain facts, events and situations in their natural environment by saying that "I think it is a research method in which phenomena and events are examined in their own natural environment.".

While a participant (S.10.PhD.F.) expressed her opinion on "multiple data source" sub-theme as "Qualitative research method is a research method enabling the detection of some results by using qualitative information collection methods or techniques without having any aim to reach a general judgment.", another participant (S.20. PhD.M.) who thinks similarly tried to explain his opinion as "It is a research in which perceptions and situations are presented in a holistic way in their natural environment by using different qualitative data collection tools such as observation and interview.". Qualitative research is expressed as a study in which social facts and events are examined using different qualitative data collection methods such as observation, interview and document analysis.

\subsection{Results Related to Strengths and Limited Aspects of Qualitative Research Method}

Opinions of social studies education graduate students on strengths and limited aspects of qualitative research method were obtained and this theme was seen to be concentrated around two sub-themes in line with these opinions. Figure 2 shows the model and number of loading for this theme. 


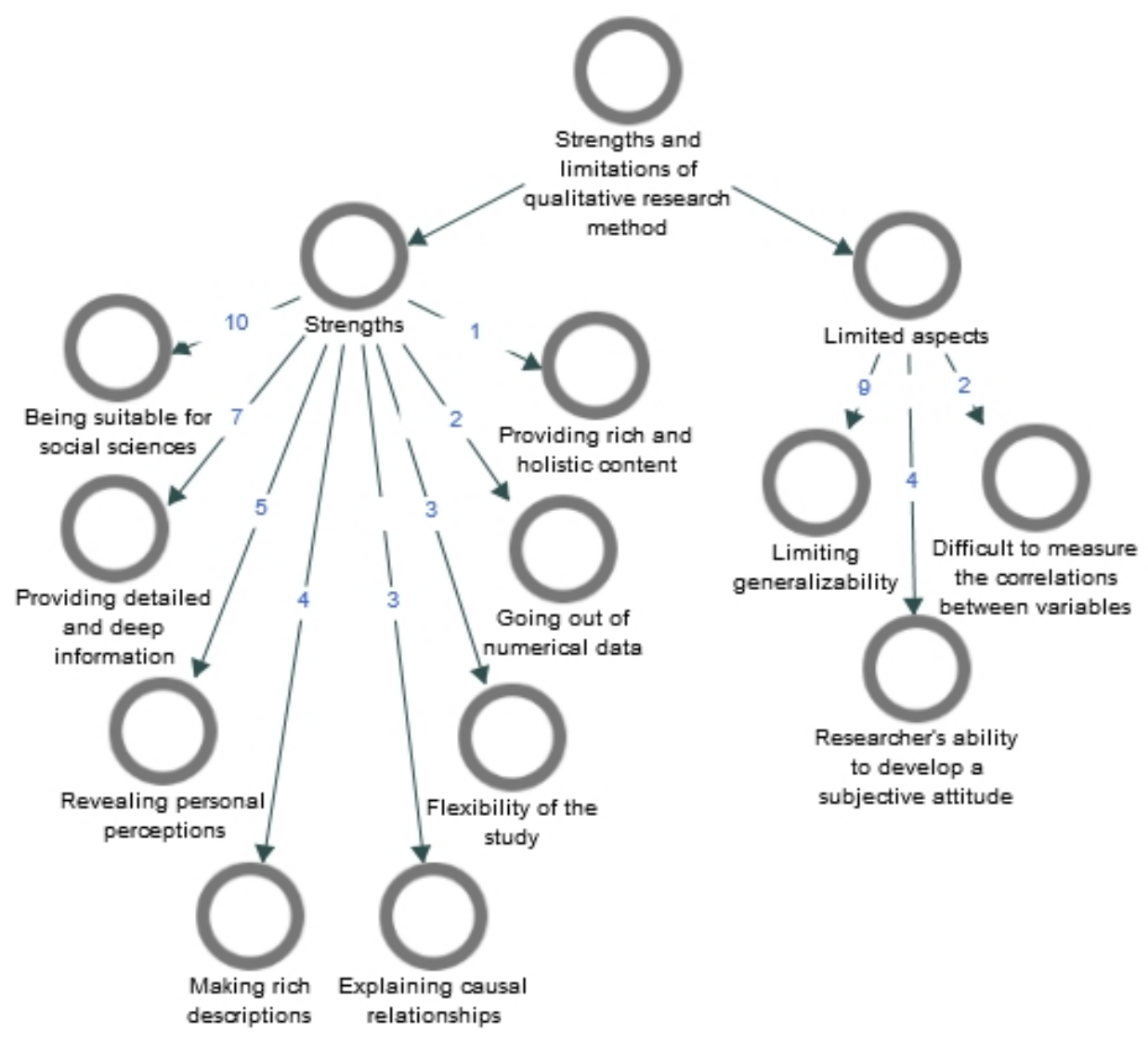

Figure 2. Model related to strengths and limited aspects of qualitative research method

When the model related to strengths and limited aspects of qualitative research method is examined, the qualitative research was seen to be divided into two sub-themes as "strengths" and "limited aspects". The graduate students expressed the "strengths" theme with the sub-theme of "being suitable for social sciences" with maximum ten loadings. The other sub-themes determined for this theme were found as; "providing detailed and deep information", "revealing personal perceptions", "making rich descriptions", "explaining causal relationships", "flexibility of the study", "going out of numerical data" and "providing rich and holistic content", respectively. The graduate students expressed "limited aspects" theme as "limiting generalizability", "researcher's ability to develop a subjective attitude" and "difficult to measure the correlations between variables". Some sub-themes and participant views are given below.

The strengths of the qualitative researches are associated with the sub-theme of "being suitable for social sciences". While a participant (S.1.M.F.) thinking that way expressed her opinion as "I think it has a very important place in the social sciences..", another participant (S.12.M.M.) expressed his theme-related opinions as "Qualitative research', being a research type used within the scope of the social sciences, examines human behaviors and interprets them according to their qualifications".

Limited aspects of qualitative researches are seen to be expressed with the sub-theme of "researcher's ability to develop a subjective attitude". Regarding this theme, the participant (S.17.M.M.) stated his opinions as "Subjective assessments have the risk of affecting results. It is difficult to generalize the obtained data."; whereas, another participant (S.20.PhD.M.) who was think that way expressed his opinions as "Personal observations, emotions, and thoughts of some researchers show their effect in data collection process of the study and the interpretation of the results. In other words, the researcher's personal perceptions and experiences affect the research process. ". In fact, the graduate students stated that some researchers reflected their personal observations, values and attitudes into the research process and this directly affected the research process in qualitative researches.

\subsection{Results Related to the Place and Importance of Qualitative Research Method in Educational Researches}

It was determined that eight sub-themes were emphasized about the place and importance of qualitative research method in educational researches. Figure 3 shows the model and number of loading for this theme. 


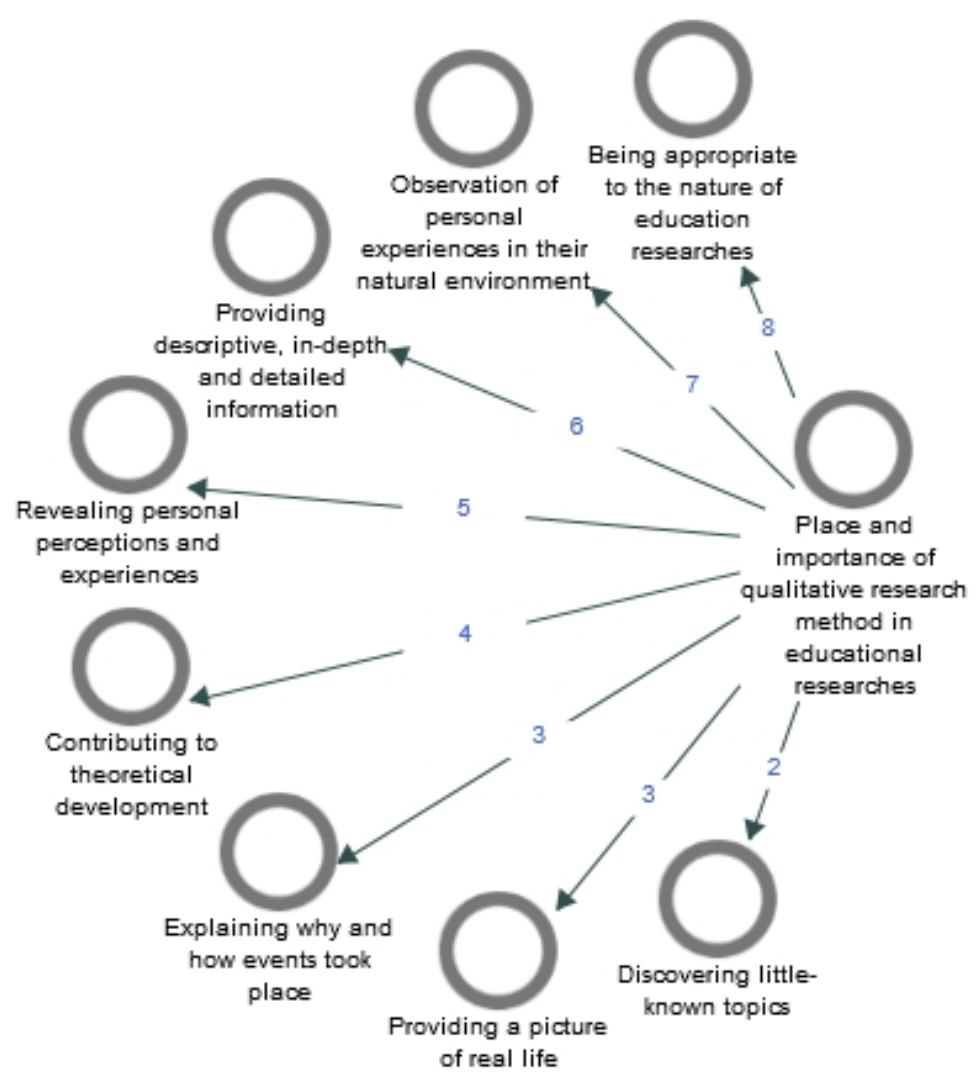

Figure 3. Model for the place and importance of qualitative research method in educational researches

When the opinions of graduate students about place and importance of qualitative research method in educational researches were evaluated, the sub-theme of "being appropriate to the nature of education researches" was expressed with maximum eight loadings. Then, the other sub-themes were expressed as; "observation of personal experiences in their natural environment", "providing descriptive, in-depth and detailed information", "revealing personal perceptions and experiences", "contributing to theoretical development", "explaining why and how events took place", "providing a picture of real life", and "discovering little-known topics", respectively. Some sub-themes and participant views are given below.

The participant (S.6.M.F.) associating the theme of place and importance of qualitative research method in educational researches with "observation of personal experiences in their natural environment" sub-theme explained her opinions as "Qualitative methods are needed in studies aiming to reveal perspectives of people in research problem in educational researchers, to understand the outside world from their perspectives, and to observe their behaviors in the natural environment.". In fact, since qualitative researches are the studies aiming to observe the experiences and behaviors of individuals in their natural environment, they have an important place in educational researches.

The participant (S.4.M.F.) explained her opinions about "Explaining why and how events happened" sub-theme as "In qualitative researches, which aim to investigate the social life, the answers of the "how" and "why" questions about a phenomenon are sought. In other words, it makes explanations about how and why a phenomenon occurs. In this respect, it has an important place in education". Another participant (S.11.M.F.) expressed his/her opinions as "Qualitative research method is a useful and important method especially since it seeks answers to why and how questions without being expressed in numerical results."

\subsection{Results Related to the Criteria to be Considered While Conducting Qualitative Research}

It was determined that there were nine sub-themes related to the criteria to be considered while conducting qualitative research. Figure 4 shows the model and number of loading for this theme. 


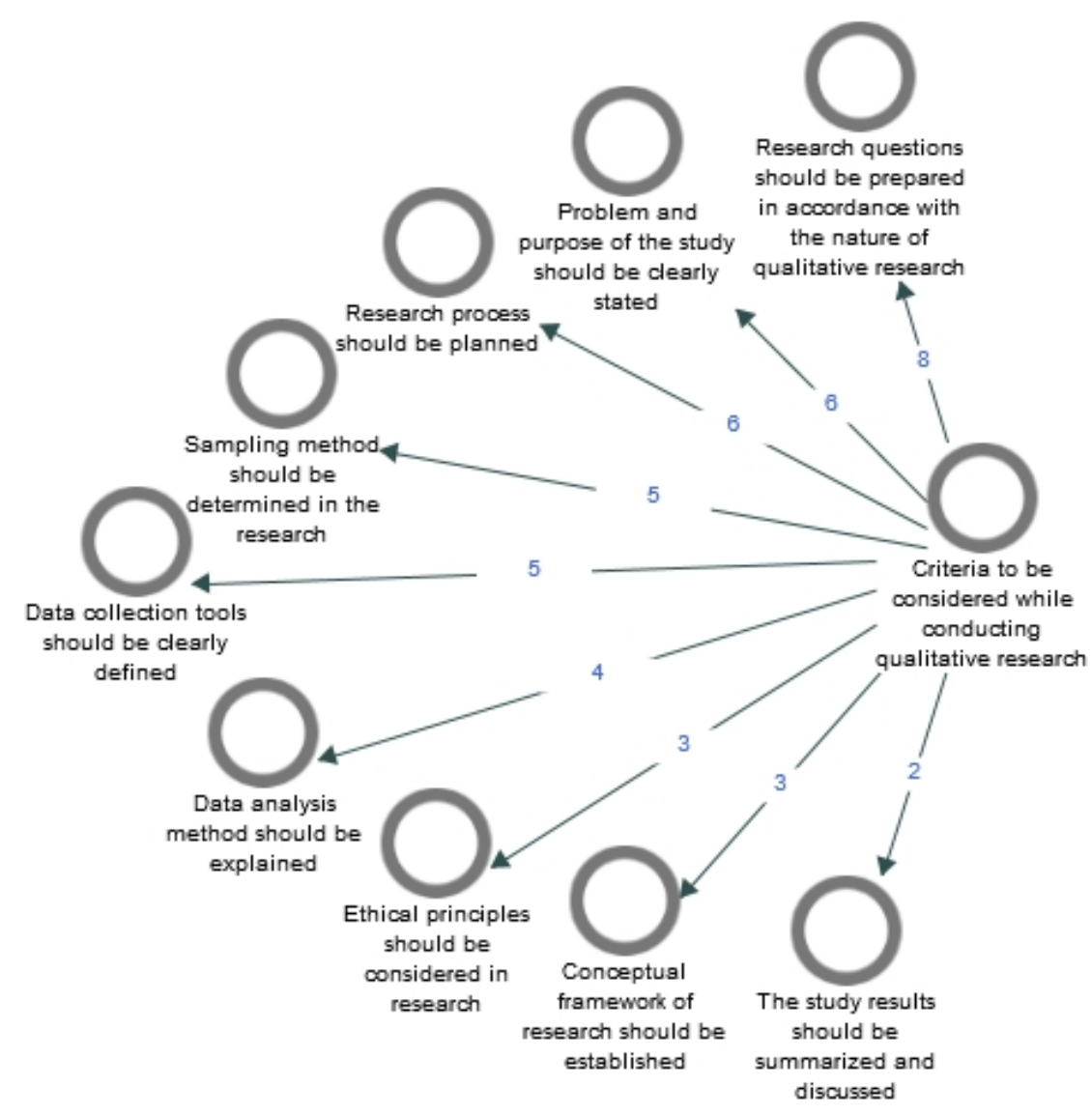

Figure 4. Model related to the criteria to be considered while conducting qualitative research

While criteria to be considered while conducting qualitative research were seen to be concentrated in "research questions should be prepared in accordance with the nature of qualitative research" subtheme with maximum eight loadings, the criteria of "problem and purpose of the study should be clearly stated" "research process should be planned", "sampling method should be determined in the research", "data collection tools should be clearly defined", "data analysis method should be explained", "ethical principles should be considered in research", "conceptual framework of research should be established" and "the study results should be summarized and discussed", respectively, were stated to be taken into account. Some sub-themes and participant views are given below.

While the participant (S.16.M.F) explaining "Research questions should be prepared in accordance with the nature of qualitative research." sub-theme expressed her opinions as "the questions prepared in the research process should be appropriate to the nature of the qualitative method, the questions should be clear and understandable and these questions should only question a single subject or area.", another participant (S.21.M.F.) stated that preparing the research questions in accordance with the nature of the qualitative research is an important step necessary to be considered in qualitative research process by saying that "In preparing the research questions, it is important first to determine the basic problem of the study and to examine the literature carefully. It is also important to prepare questions appropriate to the nature of qualitative research.".

While the participant (S.9.M.M.) expressed his opinions about "Research process should be planned" sub-theme as "While conducting a qualitative research, we must first clearly identify the main steps to be followed in the process.", another participant (S.24.M.F.) explained her opinions as "It does not matter if it is quantitative, qualitative or mixed research, it is very important that a scientific research follows a systematic and consistent process. For this purpose, the first criteria to be considered in the study is the planning of the study. The basic steps to be followed during the research process should be determined.". It was determined that they considered planning the research as important in terms of allowing to follow-up a systematic process and it is suitable for the nature of the qualitative research. 


\subsection{Results Related to Challenging Stages While Conducting Qualitative Research}

It was determined that there were eight sub-themes regarding the challenging stages while conducting qualitative research. Figure 5 shows the model and number of loading for this theme.

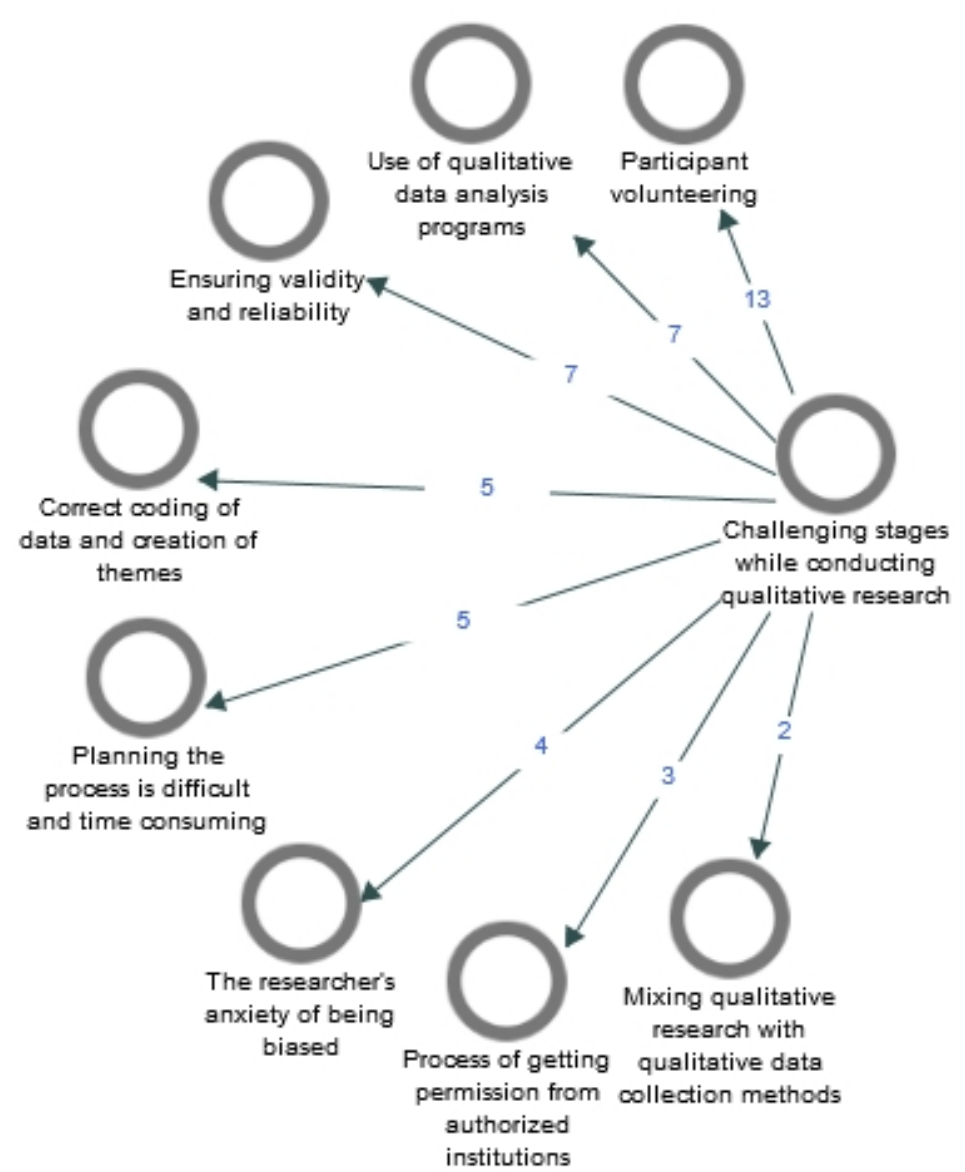

Figure 5. Model related to challenging stages while conducting qualitative research

The graduate students expressed the stages they had difficulty in conducting qualitative research as "participant volunteering", "use of qualitative data analysis programs", "ensuring validity and reliability", "correct coding of data and creation of themes", "planning the process is difficult and time consuming", "the researcher's anxiety of being biased", "process of getting permission from authorized institutions", and "mixing qualitative research with qualitative data collection methods". Some sub-themes and participant views are given below.

While the participant (S.3.M.M.) explaining "Participant volunteering" sub-theme expressed his opinions as "I am having problems about the volunteering of the participants while conducting qualitative research.", another participant (S.14.M.F.) expressed that the problems caused by the participants were experienced in the studies by stating that "Unwilling condition of the study groups in data collection stages and not responding truthfully disrupts the flow of the study.".

The participant (S.21.M.F.) expressed her opinions about the sub-theme "Correct coding of data and creation of themes" as "Doing a scientific research is not an easy task. Besides, it is not also easy to correctly code the qualitative studies containing dense data and to form the themes. In this process, I refer to the expert opinion and try to learn.". It was stated that coding data and forming themes in qualitative research involves a very tiring and intense process both physically and mentally and the researchers had problems in the correct coding of the dense data set and the formation of the themes. 
3.6 Results Related to the Recommendations for the Solution of the Problems Encountered While Conducting Qualitative Research

It was determined that there were nine sub-themes related to the recommendations for the solution of the problems encountered while conducting qualitative research. Figure 6 shows the model and number of loading for this theme.

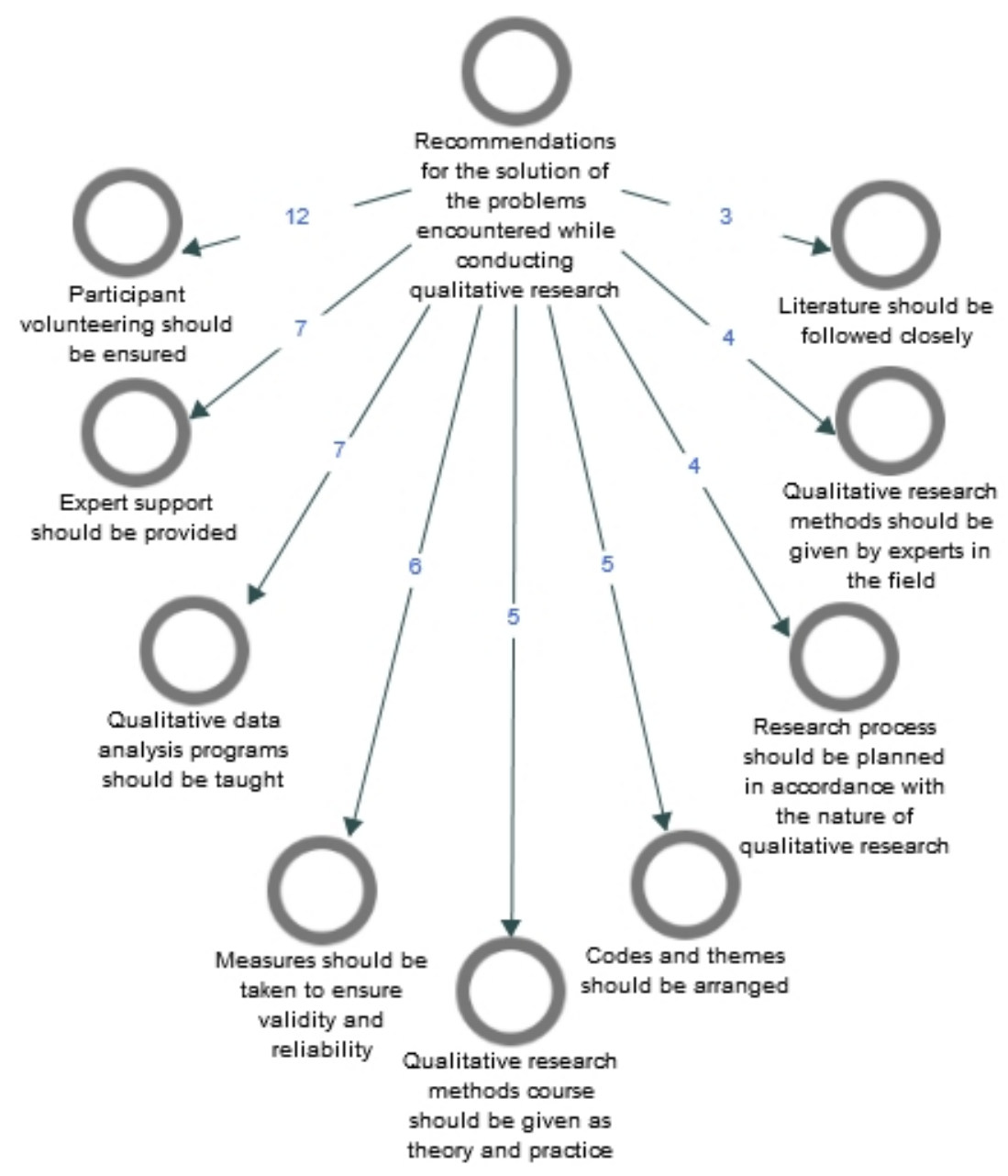

Figure 6. Model related to the recommendations for the solution of the problems encountered while conducting qualitative research

When the model related to the recommendations about the solution of these problems encountered while conducting qualitative research was examined, they were seen to give recommendations of "participant volunteering should be ensured", "expert support should be provided", "qualitative data analysis programs should be taught", "measures should be taken to ensure validity and reliability", "qualitative research methods course should be given as theory and practice", "codes and themes should be arranged", "research process should be planned in accordance with the nature of qualitative research", "qualitative research methods should be given by experts in the field" and "literature should be followed closely". Some sub-themes and participant views are given below.

While the participant (S.10.PhD.F.) explaining "Participant volunteering should be ensured" sub-theme expressed her opinion as "while participants constitute a resource for the research, they should support the researcher, be willing and informed...", another participant (S.22.M.F.) expressed her opinions as "Awareness that these research topics will be a contribution to the scientific treasure should be given to participants. The most important thing I can say about this subject is the responsibility of every education person to contribute to scientific researches.". 
The participant (S.2M.F) expressed her opinions about "Qualitative data analysis programs should be taught" sub-theme as "Analysis of qualitative researches is a complex and time-consuming process. Information about qualitative data analysis programs should be given and taught in the courses." Another participant (S.4.M.F) emphasized that planning qualitative research process was difficult and time consuming and qualitative data analysis programs should be taught in order to spend this process more efficiently by stating, "Using computer programs in the analysis facilitates the analysis process. I believe that these programs should be taught to us in the courses given."

\subsection{Results Related to Knowledge and Skill Competence in Maintaining Qualitative Research}

In accordance with the opinions of graduate students in social studies education regarding knowledge and skill competence in maintaining qualitative research, this theme was seen to be concentrated around two sub-themes. Figure 7 shows the model and number of loading for this theme.

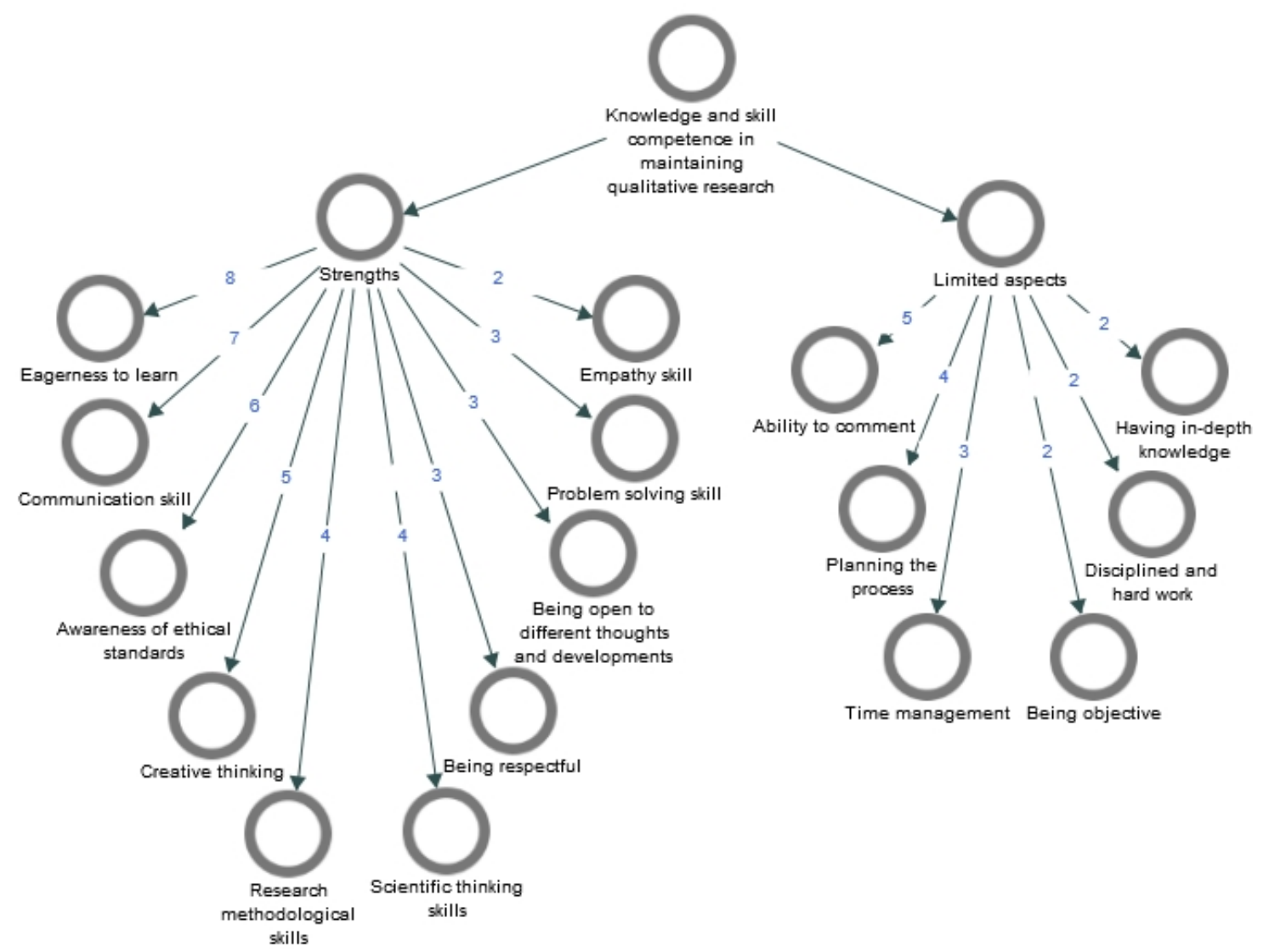

Figure 7. Model for knowledge and skill competence in maintaining qualitative research

When the model related to knowledge and skill competence in maintaining qualitative research was examined, qualitative research was seen to be divided into two sub-themes: "strengths" and "limited aspects".

It was found that there were ten sub-themes about "strengths" theme. Sub-themes determined for this theme were determined "eagerness to learn", "communication skill", "awareness of ethical standards", "creative thinking", "research methodological skills", "scientific thinking skills", "being respectful", "being open to different thoughts and developments", "problem solving skill", and "empathy skill", respectively. Six sub-themes were determined about "limited aspects" theme. The sub-themes determined for this theme were expressed as; "ability to comment", "planning the process", "time management", "being objective", "disciplined and hard work", and "having in-depth knowledge", respectively. Some sub-themes and participant views are given below.

While the participant (S.1.M.F) associating the strengths of knowledge and skill competence with "eagerness to learn" sub-theme explained her opinions as "I do not have any published study but in accordance with my assignments and studies, I know I am at the beginning of the road and I need to learn a lot of things but I believe 
that I can improve myself as long as I am open and willing to learn.", another participant (S.8.M.M) explained his opinion with "Being a willing person to do research is one of my strengths and I enjoyed the study."

While the participant, (S.13.M.M) associating the limited aspects of knowledge and skill competence with "planning the process" sub-theme, emphasized that he did not consider himself competent in planning the process but he was aware that an effective planning should be done in the qualitative research process by stating that "I do not know which path I will follow during the qualitative research process such as determining research problem, selecting sampling method, data collection and data analysis. Since I have difficulties in planning the process, I also have difficulty in using my time efficiently. But I should find a solution to this problem as soon as possible."

\subsection{Results on Knowledge and Skills Gained as a Result of Qualitative Research Experience}

It was determined that ten sub-themes were emphasized on the knowledge and skills gained as a result of qualitative research experience. Figure 8 shows the model and number of loading for this theme.

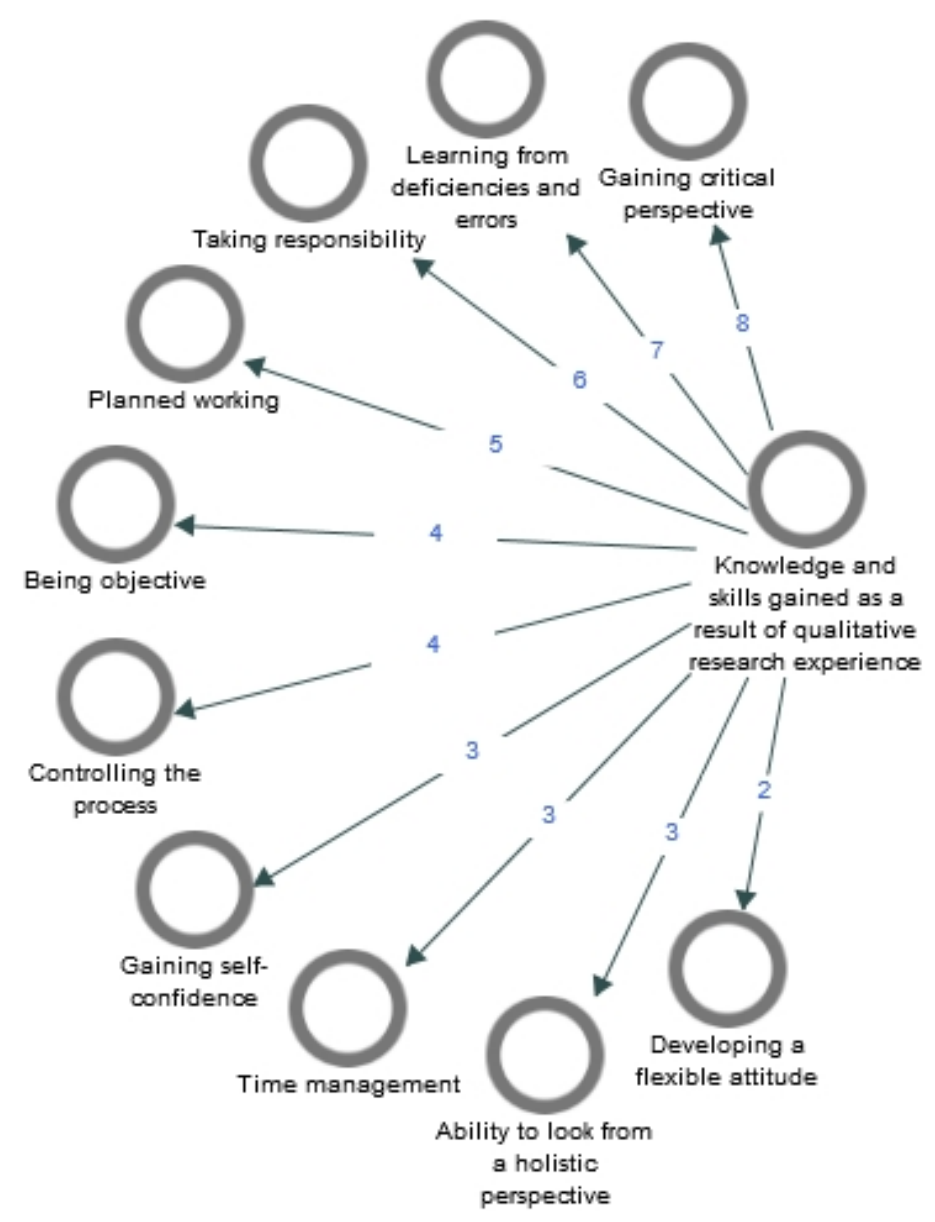

Figure 8. Model related to knowledge and skills gained as a result of qualitative research experience

When the model on knowledge and skills gained as a result of qualitative research experience was examined, the graduate students were determined to express the subthemes of "gaining self-confidence", "learning from deficiencies and errors", "taking responsibility", "planned working", "being objective", "controlling the process", "gaining critical perspective", "time management", "ability to look from a holistic perspective" and "developing a flexible attitude". Some sub-themes and participant views are given below.

While the participant (S.9.M.M) expressing his/her opinions about "Learning from deficiencies and errors" sub-theme as "In my qualitative works, I try to improve the quality of my works by eliminating my mistakes and missing points that I have seen in my previous studies", another participant (S.10.PhD.F) explained her opinions with "As a result of a qualitative research experience, we learn how to carry out qualitative researches, we have 
the opportunity to communicate with the participants directly through the researches and add new information to our knowledge. In addition, I try to make regulations for my next study by realizing my deficiencies in every qualitative study I have conducted." It was determined in the study that the mistakes and deficiencies were considered as a significant gain in learning qualitative research process. Moreover, it was emphasized that by taking lessons from these deficiencies, these deficiencies would be fixed in the next studies and the studies would be enriched.

A participant (S.23.M.M), explaining his thoughts about "Time management" sub-theme, emphasized that his/her time management has become better as a result of experiences with the sentence of "It had a positive effect on my personal development. I had great difficulties in time management, especially since I did not proceed according to a certain plan. I did not ignore this in the next studies."

\subsection{Results on Graduate Education in Teaching the Qualitative Research Method}

It was seen that the theme on graduate education in teaching the qualitative research method concentrated around two sub-themes. Figure 9 shows the model and number of loading for this theme.

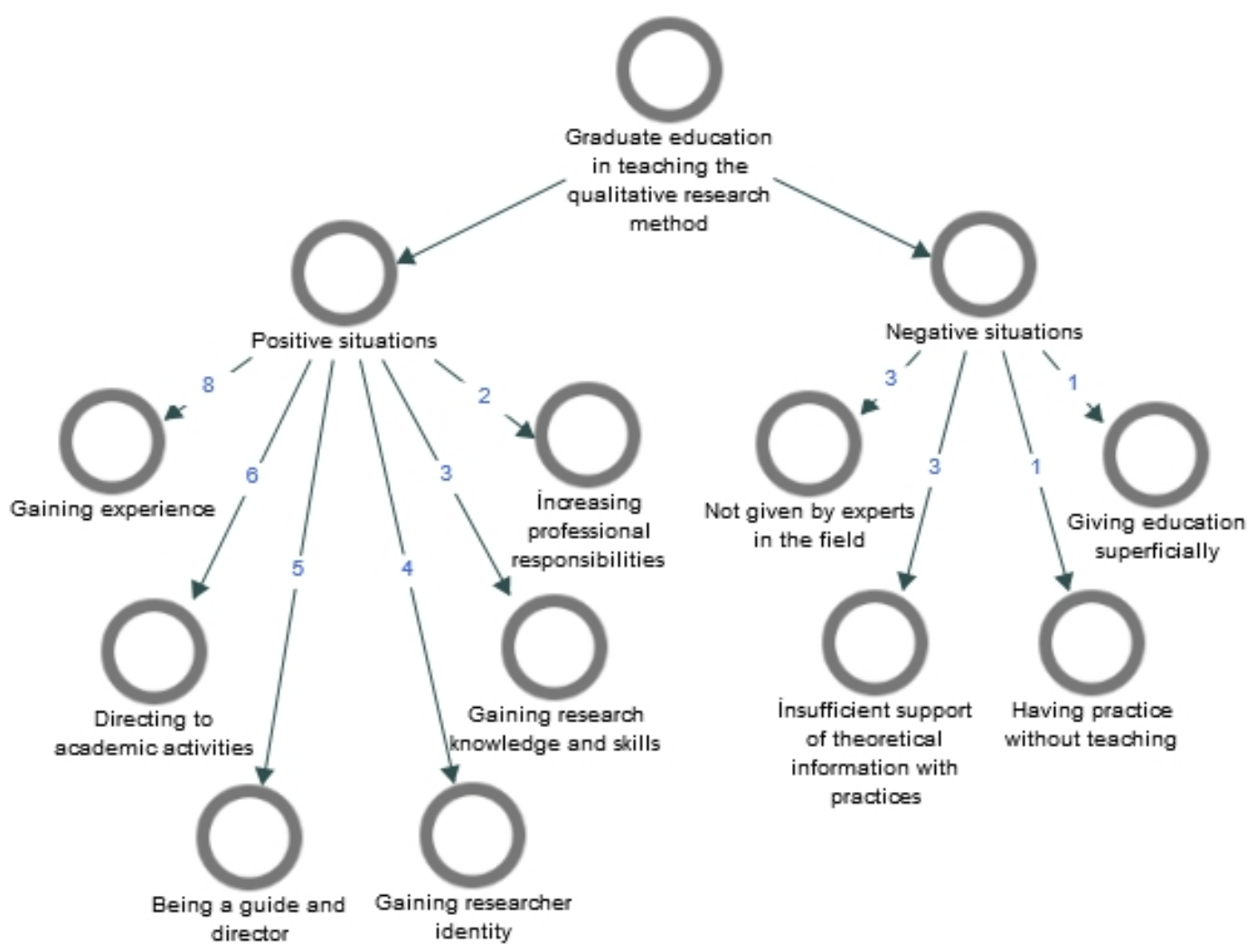

Figure 9. Model related to graduate education in teaching the qualitative research method

When the model related to graduate education in teaching the qualitative research method was examined, it was seen to be divided into two sub-themes as "positive situations" and "negative situations".

It was determined that there were six sub-themes about "positive situations" theme. The sub-themes determined for this theme were expressed as "gaining experience", "directing to academic activities", "being a guide and director", "gaining researcher identity", "gaining research knowledge and skills", and "increasing professional responsibilities", respectively. It was determined that there were five sub-themes about "negative situations" theme. The sub-themes determined for this theme were expressed as "not given by experts in the field", "insufficient support of theoretical information with practices", "having practice without teaching" and "giving education superficially", respectively. Some sub-themes and participant views are given below.

While the participant (S.1.M.F) who associated positive situations with "gaining experience" sub-theme explained her thoughts as "I take my lessons and making applications on this subject makes it easier for me to learn and I 
think my advisor makes definitely the biggest contribution on this. Both the things my advisor taught me in his/her own studies and the homework given to me to improve myself are very important, so I see it sufficient.", another participant (S.11.M.F) emphasized that the education given and the practices made for teaching qualitative research method helped them to gain experience by stating that "Education and tasks given during graduate education make us experienced in research method. However, it can be improved."

The participant (S.18.M.M) who associated negative situations with "not given by experts in the field" sub-theme explained his thoughts as "As a student who took these courses, I saw that the faculty members explaining this method are not experts in their field. I believe that such important courses should be given by the faculty members who are expert in the field just like the professor ..."

\section{Conclusion, Discussion and Recommendations}

It was determined that social studies education graduate students generally expressed the qualitative research method as "sensitivity to the natural environment". Additionally, it was seen that they defined qualitative research method as "in-depth examination of a social phenomenon", "revealing perceptions and experiences", "a long term and intense interaction process", "multiple data source", "flexibility" and "holistic approach". Similarly, in the study by Saban (2007), it was concluded that graduate students expressed the concept of qualitative research as the effort of first-hand perspective taking in the natural environment, an effort to reveal personal perception and perspectives, and an in-depth examination of a social phenomenon. In the study by Som (2017), it was observed that graduate students defined qualitative research method as providing in-depth information.

It was determined that social studies education graduate students expressed the strengths of qualitative research method as "being suitable for social sciences", "providing detailed and deep information", "revealing personal perceptions", "making rich descriptions", "explaining causal relationships", "flexibility of the study", "going out of numerical data", and "providing rich and holistic content". Similarly, in a study conducted by Şahin et al. (2019), it was determined that graduate students expressed the qualitative research method as the opportunity to acquire in-depth knowledge, allowing the researcher freedom, being more suitable for the social sciences, and giving the opportunity to make emotional and subjective comments. The limited aspects of the qualitative research method were expressed as "limiting generalizability", "researcher's ability to develop a subjective attitude" and "difficult to measure the correlations between variables". In the study by Som (2017), graduate students were observed to express the limited aspects of qualitative research as the problems in providing generalizability and objectivity. In the study by Booker (2009), the reflections of qualitative research methods on teaching were investigated and it was concluded that qualitative research methods were limited in terms of subjectivity and generalizability.

When the opinions about the importance of qualitative research method in education researches were evaluated, it was determined that graduate students considered the qualitative researches important in terms of "being suitable for the nature of educational researches", "observation of personal experiences in their natural environment", "providing descriptive, in-depth and detailed information", "revealing personal perceptions and experiences", "contributing to theoretical development", "explaining why and how events happened", "providing a picture of real life", and "discovering little-known topics".

It was observed that the graduate students expressed the criteria to be considered while conducting qualitative research as "research questions should be prepared in accordance with the nature of qualitative research.", "problem and purpose of the study should be clearly stated", "research process should be planned", "data collection tools should be clearly defined", "sampling method should be determined in the research", "data analysis method should be explained", "ethical principles should be considered in research", "conceptual framework of research should be established", and "the study results should be summarized and discussed".

It was observed that the graduate students faced some difficulties while conducting qualitative research. "Participant volunteering" was primary among these difficulties. In addition, the graduate students were seen to have difficulties in the stages like the "use of qualitative data analysis programs", "ensuring validity and reliability", "correct coding of data and creation of themes", "planning the process is difficult and time consuming", "the researcher's anxiety of being biased", "process of getting permission from authorized institutions", and "mixing qualitative research with qualitative data collection methods". Similarly, in the study by Som (2017), it was concluded that graduate students had difficulties in subjects such as correct coding of dense data set, forming themes, ensuring validity and reliability and obtaining permission from authorized institutions during qualitative research process. In their study, Li and Seale (2007) determined that PhD students had difficulties in qualitative data analysis due to uncertainties in code definition and where to start coding. In the study by Blank (2004), it was seen that the graduate students stated that they had difficulties in the stages of defining and 
analyzing codes and themes.

It was found that graduate students made some suggestions for the solution of the problems they encountered while conducting qualitative research. It was observed that the graduate students made recommendations for conducting qualitative researches effectively as "participant volunteering should be ensured", "expert support should be provided", "qualitative data analysis programs should be taught", "measures should be taken to ensure validity and reliability", "qualitative research methods course should be given as theory and practice", "codes and themes should be arranged", "research process should be planned in accordance with the nature of qualitative research", "qualitative research methods should be given by experts in the field" and "literature should be followed closely". Similar to this result, it was seen in the study by Som (2017) that graduate students made some recommendations like "the course on developing qualitative research skills should be divided into two semesters as a theory and practice at the $\mathrm{PhD}$ level, sample scientific studies on the research subjects should be read and expert support should be provided.

The graduate students were determined to express the strengths on knowledge and skill competence in maintaining qualitative research subject as "eagerness to learn", "communication skill", "awareness of ethical standards", "creative thinking", "research methodological skill", "scientific thinking skill", "being respectful", "being open to different thoughts and developments", "problem solving skill", and "empathy skill". The graduate students expressed the limited aspects on knowledge and skill competence in maintaining qualitative research as "ability to comment", "planning the process", "time management", "being objective", "disciplined and hard work" and "having in-depth knowledge". Likewise, in the study by Som (2017), graduate students were seen to express that the researcher should have effective communication skills during the qualitative research period. In their study Breuer and Schrezer (2007) emphasized that a researcher should have the skills of coping with conflicts, be open to different thoughts and be questioning in the qualitative research process.

The graduate students were determined to express the knowledge and skills they gained as a result of qualitative research experience as "gaining self-confidence", "learning from deficiencies and mistakes", "taking responsibility", "planned working", "controlling the process", "being objective", "gaining critical perspective", "time management", "ability to look from a holistic perspective", and "developing a flexible attitude". Likewise, it was concluded in the study by Ersoy (2015) that PhD students learned from their mistakes and learned to criticize themselves as a result of their first qualitative research experience.

It was determined that the graduate students evaluating graduate education in teaching the qualitative research method expressed the positive situations as "gaining experience", "directing to academic activities and environment", "being a guide and director", "gaining researcher identity", "gaining research knowledge and skills", and "increasing professional responsibilities". The graduate students were observed to express negative situations as "not given by experts in the field", "insufficient support of theoretical information with practices", "having practice without teaching", and "giving superficially education".

In the light of the results of the study, some recommendations were reached.

- Considering the intensity of the content of qualitative research methods course and this course, this course should be given in two semesters as theory and practice.

- Since qualitative research applications positively affect the knowledge and skills of graduate students concerning research, they should be more involved in the research environment and process.

- The students studying in graduate education should be effectively guided and assisted during qualitative research process by faculty members.

- Courses related to qualitative research methods should be conducted by faculty members who are experts in their fields.

- Theoretical knowledge about qualitative research methods should be supported and strengthened by practices.

- During qualitative research process, students studying in graduate education should be encouraged for and directed to academic activities.

- Researchers can be ensured to follow national and international literature closely on qualitative researches and be aware of developments.

\section{References}

Avcı, M. (2008). Bilimsel araştırmalarda veri toplama. In O. Kılıç, \& M. Cinoğlu (Eds.), Bilimsel araştırma yöntemleri (pp. 145-170). İstanbul: Lisans Yayıncılık. 
Aydın, N. (2018). Nitel araştırma yöntemleri: Etnoloji. Uluslararası Beşeri ve Sosyal Bilimler İnceleme Dergisi, 2(2), 60-71.

Balc1, A. (2011). Sosyal bilimlerde araştırma yöntem, teknik ve ilkeler (9. bask1). Ankara: Pegem Akademi.

Barrett, A. (2005). The information-seeking habits of graduate student researchers in the humanities. The Journal of Academic Librarianship, 31(4), 324-331. https://doi.org/10.1016/j.acalib.2005.04.005

Bilgin, N. (2014). Sosyal bilimlerde içerik analizi teknikler ve örnek çalı̧̧malar (3. bask1). Ankara: Siyasal Kitabevi.

Blank, G. (2004). Teaching qualitative data analysis to graduate students. Social Science Computer Review, 22(2), 187-196. https://doi.org/10.1177/0894439303262559

Booker, K. C. (2009). Shifting priorities: Reflections on teaching qualitative research methods. The Qualitative Report, 14(3), 389-394.

Breidenstein, A., Liberatore, I., Lioi, T., Miro, E., Weber, S., \& Stoeck, S. (2001). Outcomes of preservice teachers' qualitative research. The Clearing House: A Journal of Educational Strategies, Issues and Ideas, 74(3), 141-144. https://doi.org/10.1080/00098650109599180

Breuer, F., \& Schreier, M. (2007). Issues in learning about and teaching qualitative research methods and methodology in the social sciences. Forum: Qualitative Social Research, 8(1), 1-16. http://dx.doi.org/10.17169/fqs-8.1.216

Büyüköztürk, Ş., Kılıç Çakmak, E., Akgün, Ö. E., Karadeniz, Ş., \& Demirel, F. (2013). Bilimsel araşttrma yöntemleri (15. bask1). Ankara: Pegem Akademi.

Çıkrıkçı Demirtaşlı, N. (2002). Lisansüstü eğitim programlarına girişte lisansüstü eğitimi giriş sınavı (ALES) sonucunun ve diğer ölçütlerin kullanımına ilişkin bir tarama. Ankara Üniversitesi Eğitim Bilimleri Fakültesi Dergisi, 35(1-2), 61-70. https://doi.org/10.1501/egifak_0000000064

Çilesiz, Ş. (2011). A phenomenological approach to experiences with technology: Current state, promise, and future directions for research. Educational Technology Research and Development, 59(4), 487-510. https://doi.org/10.1007/s11423-010-9173-2

Cobb, A. K., \& Hoffart, N. (1999). Teaching qualitative research through participatory coursework and $\begin{array}{lllll}\text { mentorship. Journal of } & \text { Professional }\end{array}$ https://doi.org/10.1016/s8755-7223(99)80063-5

Creswell, J. W. (2016). Nitel çalışma tasarımı, A. Budak ve İ. Budak (Çev.). In M. Bütün, \& S. B. Demir (Çev. Eds.), Nitel araştırma yöntemleri beş yaklaşıma göre nitel araştırma ve araştırma deseni (pp.42-68). 2013, Ankara: Siyasal Kitabevi. https://doi.org/10.14527/9786053187486.15

Creswell, J. W., \& Miller, D. L. (2000). Determining validity in qualitative inquiry. Theory into Practice, 39(3), 124-130. https://doi.org/10.1207/s15430421tip3903_2

Denzin, N. K., \& Lincoln, Y. S. (2011). Introduction: The discipline and practice of qualitative research. In N. K. Denzin, \& Y. S. Lincoln (Eds.), The sage handbook of qualitative research (pp. 1-20). Thousand Oaks, CA: Sage Publications Inc.

Efinger, J., Maldonado, N., \& McArdle, G. (2004). Phd students' perceptions of the relationship between philosophy and research: A qualitative investigation. The Qualitative Report, 9(4), 732-759.

Erlandson, D. A., Harris, E. L., Skipper, B. L., \& Allen, S. D. (1993). Doing naturalistic inquiry: A guide to methods. California: Sage Publications.

Ersoy, A. (2015). Doktora öğrencilerinin ilk nitel araştırma deneyimlerinin günlükler aracılığıyla incelenmesi. Pegem Ĕ̈itim ve Öğretim Dergisi, 5(5), 549-568. https://doi.org/10.14527/pegegog.2015.030

Harman, G., \& Şeker, R. (2019). Fen bilgisi öğretmen adaylarının bilimsel araştırma yapmaya yönelik metaforik algıları. Pamukkale Üniversitesi Sosyal Bilimler Enstitüsü Dergisi, 35, 109-123. https://doi.org/10.30794/pausbed.446702

Işıksoluğu, M. K. (1993). Bilimsel yayınlarda dürüstlük boyutu. Eğitim ve Bilim, 17(90), 3-7.

Karasar, N. (2004). Bilimsel araştırma yöntemi (13. Baskı). Ankara: Nobel Yayın Dağıtım.

Karataş, Z. (2015). Sosyal bilimlerde nitel araştırma yöntemleri. Manevi Temelli Sosyal Hizmet Araştırmaları Dergisi, 1(1), 62-80. 
Kartarı, A. (2017). Nitel düşünce ve etnografi: etnografik yönteme düşünsel bir yaklaşım. Hacettepe Üniversitesi İletişim Fakültesi Kültürel Çalışmalar Dergisi, 4(1), 207-220. https://doi.org/10.17572/mj2017.1.207220

Li, S., \& Seale, C. (2007). Learning to do qualitative data analysis: An observational study of doctoral work. Qualitative Health Research, 17(10), 1442-1452. https://doi.org/10.1177/1049732307306924

McCusker, K., \& Gunaydin, S. (2015). Research using qualitative, quantitative or mixed methods and choice based on the research. Perfusion, 30(7), 537-542. https://doi.org/10.1177/0267659114559116

Miles, M. B., \& Huberman, A. M. (2016). Analizde ilk adımlar, A. Ersoy (Çev.). In S. Akbaba Altun, \& A. Ersoy (Çev. Eds.), Genişletilmiş bir kaynak kitap: Nitel veri analizi (pp. 50-88). 1994, Ankara: Pegem Akademi.

Öztemel, E. (2013). Yükseköğretim kurumlarında araştırma ve inovasyon kültürünün oluşturulması. Yüksekögrretim Dergisi, 3(1), 22-29. https://doi.org/10.2399/yod.13.006

Patton, M. Q. (2014). Nitel araştırmanın doğası, M. Bütün ve S. B. Demir (Çev.). In M. Bütün, \& S. B. Demir (Çev. Eds.), Nitel araştırma ve değerlendirme yöntemleri (pp. 3-36). 2000, Ankara: Pegem Akademi.

Rifkin, S. B., \& Hartley, S. D. (2001). Learning by doing: Teaching qualitative methods to health care personnel. Education for Health, 14(1), 75-85.

Saban, A. (2007). Lisansüstü öğrencilerin nitel araştırma metodolojisine ilişkin algıları. Selçuk Üniversitesi Sosyal Bilimler Enstitüsü Dergisi, 1(17), 469-485.

Saban, A. (2009). Öğretmen adaylarının öğrenci kavramına ilişkin sahip oldukları zihinsel imgeler. Türk Eğitim Bilimleri Dergisi, 7(2), 281-326.

Saban, A., Koçbeker Eid, B. Nazlı., Saban, A., Alan, S., Doğru, S., ... Tunç, P. (2010). Eğitimbilim alanında nitel araştırma metodolojisi ile gerçekleştirilen makalelerin analiz edilmesi. Selçuk Üniversitesi Ahmet Keleşoğlu Ë̆itim Fakültesi Dergisi, 30, 25-142.

Şahin, Y., Uysal, S., Saraç, L., \& Gündoğdu, K. (2019). Nitel araştırma dersinin lisansüstü öğrenciler ve öğretim elemanlarınca bütüncül olarak değerlendirilmesi. Eğitimde Nitel Araştırmalar Dergisi, 7(4), 1408-1429. https://doi.org/10.14689/issn.2148-2624.1.7c.4s.5m

Saracaloğlu, A. S. (2008). Lisansüstü öğrencilerin akademik güdülenme düzeyleri, araştırma kaygıları ve tutumları ile araştırma yeterlikleri arasındaki ilişki. Yüzüncü Yıl Üniversitesi Eğitim Fakültesi Dergisi, 5(2), 179-208.

Saracaloğlu, A. S., \& Kaşlı, A. F. (2001). Öğretmen adaylarının bilgisayara yönelik tutumları ile başarıları arasındaki ilişki. Ege Eğitim Dergisi, 1(1), 110-126.

Seidman, I. (2006). Interviewing as qualitative research: A guide for researchers in education and the social sciences. New York: Teachers College Press.

Som, İ. (2017). Lisansüstü eğitim gören öğrencilerin nitel araştırma becerilerine ilişkin ihtiyaçlarının incelenmesi. Ĕ̈itim ve Ögretim Araştırmaları Dergisi, 6(4), 255-265.

Tavşanc1l, E., \& Aslan, E. (2001). Sözel, yazılı ve diğer materyaller için içerik analizi ve uygulama örnekleri (1. bask1). İstanbul: Epsilon Yayıncılık.

Turner, G. W., \& Crane, B. (2016). Teaching and learning qualitative methods through the dissertation advising relationship: Perspectives from a professor and a graduate. Qualitative Social Work, 15(3), 346-362. https://doi.org/10.1177/1473325015626260

Yıldırım, A. (1999). Nitel araştırma yöntemlerinin temel özellikleri ve eğitim araştırmalarındaki yeri ve önemi. Ë̆itim ve Bilim, 23(112), 7-17.

Yıldırım, A., \& Şimşek, H. (2016). Sosyal bilimlerde nitel araştırma yöntemleri (10. baskı). Ankara: Seçkin Yayıncilik.

\section{Copyrights}

Copyright for this article is retained by the author(s), with first publication rights granted to the journal.

This is an open-access article distributed under the terms and conditions of the Creative Commons Attribution license (http://creativecommons.org/licenses/by/4.0/). 